\title{
Biographical Research and Institutional Archives: the Case of the Inns of Court
}

\section{Guy Holborn}

\begin{abstract}
The Holy Grail for most biographical researchers is a large hoard of unpublished personal papers such as letters or diaries. In reality that quest will usually be in vain. Research must instead focus on institutional sources. Because of their long history and pervasive role in the English legal profession, the Inns of Court and their records are likely to be the starting point for many legal biographical research projects. They also very usefully illustrate what the biographical researcher is likely to gain (and unlikely to gain) from using institutional archives in general. The article goes on to describe the main classes of records held in the Inns' archives and what they can yield.
\end{abstract}

\section{Biography}

Guy Holborn has been Librarian of Lincoln’s Inn Library since 1985, having started his career at the Institute of Advanced Legal Studies and the House of Lords Library. His book Sources of biographical information on past lawyers (BIALL, 1999) was based on articles that won the first Wallace Breem Memorial Award in 1992. He received the BIALL-Wildy Law Librarian of the Year award in 2007, and is currently a member of the Editorial Board of Legal Information Management.

Gwynedd Parry in her interesting recent article in Legal Studies, "Is legal biography really legal scholarship?”, comments that "all biographers must have the dirt of dusty archives under their fingernails”. 1 This paper looks at how you might get your hands dirty at the Inns of Court, salubrious though they otherwise are.

The subjects of legal biographical research may have come from a variety of legal backgrounds, but a high proportion will have been members of one of the Inns of Court. The Inns of Court also loom large in legal biographical research simply because of their longevity as institutions. Records for Lincoln's Inn survive from 1422 and for the other Inns from not much long after. The Inns of Court are also a pertinent example of institutional archives in general, and show what such archives cannot provide as much as what they can. Institutions do not generate records for the convenience or interest of biographical researchers from generations yet to come. They are typically administrative records that are simply necessary for their day to day running, which in a few cases it is expedient to preserve but in many others have survived only through the historical accident that no one has bothered to throw them away. 


\section{Institutional archives as distinct from personal papers}

And the first practical point I wish to make - a fairly basic, but necessary one - is the distinction between institutional records on the one hand and personal papers on the other, which often boils down, though not exclusively, to the distinction between archives and libraries. The Holy Grail for most biographical researchers is a large hoard of original correspondence, drafts of writings - or even diaries in some form all unpublished, and all previously undiscovered (and of course all conveniently legible and located in a congenial part of the world for which a travel grant is readily available). One of course may be supremely lucky, but generally speaking if there is such material it will be previously known about and be recorded in catalogues of various kinds. A search on the personal indexes of the National Register of Archives ${ }^{2}$ is usually the obvious starting point, and while it is true that the location of many items in the nature of personal papers found there will be "archives" such as local record offices and so on, the manuscript collections in libraries are just as likely to be the relevant repository.

At the Inns of Court this is a particularly important consideration, since their manuscript collections and their archives are separately held, listed and administered. This is the case even at Lincoln's Inn where the archives are departmentally part of the Library; at the other Inns the archives do not even have that connection and are part of their central administration (known for historical reasons at all the Inns as the Treasury Office).

Furthermore, even if an enquiry to the Inns relating to personal papers were directed to the right quarter, the results are almost certainly going to be disappointing. Lincoln's Inn Library has by far the largest collection of the Inns of manuscript material, yet there is but a handful of items that could be described as "personal papers". The bulk of the collections were built up as working tools for the lawyer particularly law reports, collections of counsel's opinions, drafting precedents and so on. Occasionally this material may be of tangential interest to the biographical researcher, but the general message is “don't raise your hopes”.

\section{The uses of institutional archives and the Inns' records}

This is where institutional archives come in. What they can provide is fragmentary or piecemeal - single facts of little moment in their own right, but which cumulatively help to build up a picture. Before proceeding to give some examples of this from the Inns' records, it is also worth mentioning two other important uses of institutional archives in general and of the Inns' records in particular for biographical research.

First, only a proportion of the Inns records relate to individuals. The bulk of the archives are generated for institutional purposes, so on the face of it is of little interest to the biographical researcher, though of course they are a very rich source for those studying the history and functions of the Inns themselves as bodies. Nonetheless, in my experience enquirers frequently follow up with supplementary questions - for example about the rules and regulations for admission and call, about the costs involved by way of fees or chambers rent, about disciplinary procedures, about attendance and dining requirements, and so on. This may be in order to understand 
the context of the individual's involvement with the Inn, or to highlight any exceptional aspects of the individual's time at the Inn. Or the biographer may simply be after a little colour to bring their narrative to life, "colour" perhaps being simply a more low-brow version of "context". That the subject attended the Inn on x number of occasions between that date and another in order to keep terms by dining may well be a relevant biographical fact, but at what time was dinner served and what did they eat?

The second application is for the purposes of collective biography or prosopography. The latter term, which has its origins in the methods of certain nineteenth-century German classicists, has been given a wider circulation by Sir John Baker in particular, and has most recently found its apotheosis in his monumental The men of court 1440 to $1550 .^{3}$ He opens his preface by quoting from a 1945 paper by K.B. McFarlane: "medieval society 'would only reveal its secrets to the investigator who can base his conclusions upon the study of hundreds of fragmentary biographies'”. 4 The medieval period is beyond the scope of this paper, but collective biography remains a powerful tool whatever period is under consideration. This only needs citation of the leading works on the history of the bar, the Inns and the legal profession to demonstrate, namely Wilfrid Prest's two books on the period 1590 to $1640,{ }^{5,6}$ David Lemmings's two books on the eighteenth century, ${ }^{7,8}$ and the two books by Duman ${ }^{9}$ and by Cocks ${ }^{10}$ respectively on the nineteenth century. There is explicit prosopography in Prest's and Lemmings's books in the form of appendices providing "mini-biographical dictionaries" of large samples of benchers and barristers, but implicit prosopography clearly informs all these books throughout.

Collective biography can also be a worthwhile project in its own right. For example, Patrick Polden for the purpose of his important article on women at the bar from 1919 to $1939^{11}$ compiled a complete biographical listing of all the women who were admitted to the Inns. I would suggest, however, that this type of research is also relevant to anyone undertaking writing the biography of an individual. A picture of the educational, social, religious background of a cohort of the subject's contemporaries might be revealing.

Coming now to the nitty-gritty of what the Inns' archives comprise, it is worth saying that in many cases what is to be found is often very slight indeed - typically date of admission as a student member and date of call to the bar, if indeed called, will be about it. If a person is very famous, further tiny details may be ends in themselves. So, for example, it was something of a triumph for Thomas More scholarship when the long running scholarly dispute as to which of two possible dates was his date of birth was only recently settled with the help of records at Lincoln's Inn. ${ }^{12,13}$ But minutiae can also occasionally be unusually significant in more mundane research. An interesting recent example I had was the question whether a certain political figure of the early twentieth century had been present or not at a conference in India. The figure was a bencher of Lincoln's Inn, as many politicians have been, and a regular attender at meetings of Council. As the original minutes record the names of those present, one could look through at the relevant dates, calculated with reference to estimates for the time it took for a sea passage from England to India at the time, in order to see whether it would have been a physical impossibility for him to have been in two places at once. 


\section{Membership records}

Starting with membership records, the admission registers in which those joining the Inn as student members are entered have long been the most important class of record. At Lincoln's Inn they form a separate class from 1558. The standard modern format for all the Inns' registers is to provide, apart from the date of admission, age (but not date of birth), name and occupation of father, and place of origin (or latterly an address) - all basic but useful stuff. The provision of these elements is reduced as one goes back. There are variations between the Inns in this, but at Lincoln's Inn no age is given before 1805 and before 1565 it is usually only the name that is recorded.

As with the registers of Oxford and Cambridge and the major public schools, the admission registers were long deemed worthy of putting into print, and so are readily accessible, though in the case of Gray's Inn ${ }^{14}$ and Lincoln's Inn $^{15}$ they only go up to 1889 and 1895 respectively, requiring recourse thereafter to unpublished records. Middle Temple's latest supplement takes theirs to as recently as $1989 .^{16}$ Inner Temple, having only previously had a rather unsatisfactory printed version for a short period to 1660, has leapfrogged the other Inns by having an excellent full-blown, freely available online database which goes to $1920 .{ }^{17}$ With an important exception in the case of the Lincoln's Inn registers that is mentioned below, the printed versions include all the information that is to be found in the original registers. They also are arranged chronologically like the originals (but with indexes by name). This can be very useful if you are looking for contemporaries of the person in question (and in the case of Inner Temple the database allows for searches by date). This also illustrates the importance of archival integrity. As it happens, an example where archival integrity was not maintained was the edition of the admission papers of King's Inns, ${ }^{18}$ the Irish Inn of Court in Dublin, where on publication they were re-ordered alphabetically, which was a questionable editorial decision; ${ }^{19}$ worse was that apparently some of the original papers were also re-ordered as a result. ${ }^{20}$

In these matters, I am afraid to say that Lincoln's Inn is not without blemish. The first two volumes of the printed admission registers published in 1896 not only omitted the names of the "manucaptors", which appear in the originals and whose importance I will explain, but did so silently. "Manucaptors" were two existing members of the Society who until 1768 were required to stand as sureties for the payment of dues, and they signed the entry in the registers. Their names can be of considerable interest because they tended to be kinsmen, close family friends, or those from whom patronage was sought. The first scholar to exploit these possibilities in a significant way was Jason Peacey, when working on the History of Parliament project. His resulting paper is most valuable. ${ }^{21}$

Records of call to the bar form the other main class of membership records fully to survive at all four Inns. It should be appreciated, however, that a high proportion of the student membership never proceeded to be called to the bar. In recent times this is accounted for by those who simply did not manage to pass the bar exams, or changed their minds about a choice of career. But up to the nineteenth century a large number of people consciously joined the Inns with no intention of proceeding to be called. This reflected the important role of the Inns, to the fore in the sixteenth and seventeenth centuries, as finishing schools for the sons of the gentry as much as law schools. 
Beyond giving a date, call records are not in fact particularly informative. At Lincoln's Inn you get the name of the bencher who proposes call, but I do not think that usually implied any particular acquaintanceship. The bar books, unlike the admission registers, are actually signed by the candidate - very occasionally of use to the serious researcher needing to authenticate another putative document; otherwise only of autograph-hunting interest.

Apart from admission and call records, the survival of archival material in the form of membership records is rather more sporadic and variable between the Inns, particularly before the twentieth century. At Lincoln's Inn there are some seventeenth century records relating to keeping commons, which are very valuable as they indicate whether the student was actually in residence during the learning vacations (so a "serious" student), but they only survive in a relatively short run. From 1914 to date there is a series of what might be called "membership files", which generally only contain small snippets beyond the admission registers, such as names of referees, university degrees and so on. Very occasionally, however, they come up trumps. I was able to find in these files some very interesting correspondence about the admission in 1920 of Gwyneth Thomson - Gwyneth Bebb, the subject of Rosemary Auchmuty's paper. ${ }^{22}$

One surprising omission from the archival sources is generally any systematic record of dates of death of members. At Lincoln's Inn we do have a huge ledger called "The Register of Members" for the eighteenth and nineteenth centuries where this may be recorded, and for the early twentieth century the personal account ledgers, recording payments of dining dues and other fees, may be marked up with a date of death (and also can usefully give personal addresses), but it is very hit or miss.

\section{Governing body records}

By far the most generally important archival series at all the Inns is the minutes of the governing bodies of benchers, though biographical information on individuals is only usually to be gained from them by a side wind. The governing body is called Council at Lincoln’s Inn, Parliament at Inner and Middle Temples, and Pension at Gray’s Inn. There are printed editions of their minutes for them all, although up to varying dates. $^{23,24,25,26}$ The printed editions also vary as to the extent which they have been transcribed or only edited down. Certainly even at Lincoln's Inn, whose Black Books, as the minutes are called, run to six fat printed volumes and now go up to 1965, there is much minutiae that has been neither transcribed nor extracted - for the simple reason that the originals on which they are based amount to some fifty substantial volumes. They are probably of most value for those members who themselves became benchers and were active in the affairs of their Inn, but even then it should be appreciated that what is being recorded is simply the domestic activities they were involved in, although these may sometimes entail some "external affairs". The main interest for individuals who did not become benchers resides in petitions to the bench, typically for some form of exemption from the admission or call requirements, such as the number of terms to be kept, or in the later period from sitting certain exams. The bulk of these are going to be routine, but they do occasionally state, or allude to, personal circumstances giving rise to the petition. A very prominent example is Judah Philip Benjamin, the great American lawyer whose 
name lives on in the textbook Benjamin on the Sale of Goods. He provided two lengthy petitions relating to his admission to and call by Lincoln's Inn in 1866. The first sought exemption from the preliminary examination, which by then was required for admission by those students who had not attended a British university. It recites the facts that he had been called to the United States bar for thirty years, the last thirteen mainly practising in the Supreme Court, and that he held high office in the Confederate government, including Attorney General, and was now a political exile. "Ordered that under the special circumstances, the Preliminary Examination be dispensed with in the case of Mr Benjamin”. Unsurprisingly Benjamin's petitions are given in full in the printed edition of the Black Books, but most such petitions are not. An example is that of 1874 from Ng Achoy, better known as Wu Ting-Fang, the first Chinese to be admitted and later a leading legal and political figure in Hong Kong and modern China, responsible among other things for the new Chinese Criminal Code and first Commercial Code. Like Benjamin's his petition is for exemption from the preliminary examination. After reciting his background and career to date in Hong Kong (of factual interest), he concludes, providing a very small but evocative personal touch, "I trust my Lords and Gentlemen that you will be pleased to grant me a favourable reply as early as possible, as, among other things, my taking of rooms and adopting English costume must remain in abeyance till I learn the result of this application”.

As well as meeting in plenary form, from the nineteenth century the benchers conducted much business in committees, the number of which multiplied during the twentieth century, and their papers and minutes usually survive, although before the days of word-processors and photocopiers they are necessarily often fairly terse. One early twentieth century committee at Lincoln's Inn that can be useful was on "Reading in Chambers", i.e. pupillage. Although pupillage only became compulsory in 1958 (and incidentally until then was generally undertaken before call rather than after), it had long been a necessary pre-requisite to practice. As it was an entirely private arrangement (and was not compulsory), the Inns had no reason to keep any records of it, which is a frequent disappointment to enquirers - a pupil master could of course be a very important influence on their pupil's later career and their identity thus important. The Inns, however, did start to award scholarships to defray the cost of pupillage - of course you paid your pupil master, not the other way round, the standard fee being 100 guineas - and the minutes will identify the pupil master, if such a scholarship were awarded.

\section{Property records}

A very large class in the Inns' archives relates to their property, including the letting of chambers. Where someone had their chambers, though not particularly significant in itself, is the sort of fact a biographer likes to know. There are the directories giving barristers' chambers that have been published since the late eighteenth century, notably the Law List, ${ }^{27}$ but at first they far from comprehensive, so the Inn's records can help and some members were also residents. The records may also contain incidental information. For example, the chambers records at Lincoln's Inn show that Jeremy Bentham compounded for absent commons in 1776, showing that he did not keep terms in the Inn and that in 1813 he surrendered his chambers to his nephew Samuel Bentham. 


\section{Disciplinary records}

Disciplinary matters, if such befell the person in question, would of course be potentially deeply revealing. But here again the quantity of material before the twentieth century is fact very sparse, largely because such proceedings were surprisingly uncommon. Up until the late seventeenth century you do get from time to time domestic incidents, often quite colourful such as striking the chief porter with a sword or fornicating in the garden, or internal matters of a more prosaic nature such as non-payment of dues or rent, but there are virtually no cases of professional misconduct leading to disbarment until relatively recently. The most famous nineteenth century case was that of Edward Kenealy who was disbarred and disbenched by Gray's Inn in 1874, following his defence of the Tichborne claimaint. It is generally supposed that it was his professional conduct of that case that led to his disbarment, though in fact it was his editorship of a scurrilous journal, bringing his Inn and the profession into disrepute that was the nub of the charges. But that case was practically unique. Otherwise, the ones that do turn up in the nineteenth century and a little later tend to be laconic, and relate to criminal convictions, which were indeed recognised as good cause for disbarment even by the Inns.

At Lincoln's Inn the most notorious case in modern times, which has some legal historical interest, was the Marrinan case in 1957, which resulted in an unprecedented five-day public hearing conducted in the Old Hall. The barrister, Marrinan, had some extremely dodgy associates, including an East End gangster by the name of Billy Hill. Marrinan faced a whole string of charges of professional misconduct relating to these characters which in the end were amply proved. The wider interest of the case is that it arose from police intercepts of Hill's telephone, which included conversations with Marrinan. The Home Secretary, no less, having got wind of the intercepts passed them to the Bar Council, and as they were a crucial part of the evidence there was much discussion as to their admissibility at the hearing, and if admissible whether the hearing could be in public. Furthermore it opened up a huge can of worms as to the authority to make phone taps in the first place, and as to the authority of the Home Secretary to pass them to a third party. The very first official inquiry, the Birkett report, ${ }^{28}$ on the legality of phone tapping ensued (which concluded, incidentally, that the decision to disclose the intercepts to the Bar Council and the benchers of Lincoln’s Inn had plainly been wrong).

\section{Further information}

This paper has not by any means exhausted all the archival sources that might be of relevance to the biographical researcher, concentrating on those most like to be of use, and there is a certain bias to what is available at Lincoln's Inn. A good deal of further information on their archives will be found on each of the Inns' websites, though none of their full archives catalogues are currently freely available externally online. Each of the Inns, however, has a professional Archivist (either full-time or part-time) who is always very willing to answer enquiries from outside scholars. 


\section{Footnotes}

${ }^{1}$ Parry, Gywneth. (2010) Is legal biography really legal scholarship? Legal Studies 30(2), 208-229 at 225

${ }^{2}$ National Register of Archives http://www.nationalarchives.gov.uk/nra/

${ }^{3}$ Baker, Sir John. (2012) The men of court 1440 to 1550: a prosopography of the Inns of Court and Chancery and the courts of law. London, Selden Society (Selden Society supplementary series; vol. 18). 2 vols

${ }^{4}$ McFarlane, K.B. (1945) Bastard feudalism. Bulletin of the Institute of Historical Research 20(61), $161-180$ at 175

${ }^{5}$ Prest, Wilfrid R. (1972) The Inns of Court under Elizabeth I and the early Stuarts 1590-1640.

London, Longman

${ }^{6}$ Prest, Wilfrid R. (1986) The rise of the barristers: a social history of the English bar 1590-1640. Oxford, Clarendon Press

${ }^{7}$ Lemmings, David. (1990) Gentlemen and barristers: the Inns of Court and the English bar 16801730. Oxford, Clarendon Press

${ }^{8}$ Lemmings, David. (2000) Professors of the law: barristers and English legal culture in the eighteenth century. Oxford, Oxford University Press

${ }^{9}$ Duman, Daniel. (1983) The English and colonials bars in the nineteenth century. London, Croom Helm

${ }^{10}$ Cocks, Raymond. (1985) The foundations of the modern bar. London, Sweet \& Maxwell

${ }^{11}$ Polden, Patrick. (2005) Portia’s progress: women at the bar in England 1919-39. International Journal of the Legal Profession 12(3), 293-338

${ }^{12}$ Mitjans, Frank. (2010) The date of birth of Thomas More. Moreana 47(181/182), 109-128

${ }^{13}$ Mitjans, Frank. (2012) Reviewing and correcting the article on the date of birth of Thomas More. Moreana 49(189/190), 251-262

${ }^{14}$ Foster, Joseph. (1889) The register of admissions to Gray’s Inn, 1521-1889. London, Privately printed

${ }^{15}$ Lincoln's Inn. (1896) The records of the Honorable Society of Lincoln's Inn: admissions and chapel registers, 1420[-1895]. London, Lincoln's Inn. 2 vols

${ }^{16}$ Middle Temple. (1949-1998) Register of admissions to the Honourable Society of Middle Temple 1501[-1989]. London, Middle Temple. 6 vols

${ }^{17}$ Inner Temple Admissions Database 1547-1920 http://www.innertemplearchives.org.uk/index.asp

${ }^{18}$ King's Inns. (1982) King's Inns admission papers 1607-1867. Dublin, Stationery Office for the Irish Manuscripts Commission

${ }^{19}$ Kenny, Colum. (1990) “The records of King’s Inns, Dublin” in Hogan, Daire and Osborough, W.N. (eds) Brehons, serjeants and attorneys: studies in the history of the Irish legal profession. Blackrock, Irish Academic Press, 1990. 231-247

${ }^{20}$ Cochrane, Nigel (1989) The archives and manuscripts of King's Inns Library. Irish Archives 1, 2530 (cited in the above at footnote 5)

${ }^{21}$ Peacey, J.T. (1997) Led by the hand: manucaptors and patronage at Lincoln's Inn in the seventeenth century. Journal of Legal History 18(10), 26-44

${ }^{22}$ Auchmuty, Rosemary. (2011) Whatever happened to Miss Bebb? Bebb v The Law Society and women's legal history. Legal Studies 31(2), 199-230, the research for which was the subject of the author's paper at the 2013 Legal Biographies Seminar.

${ }^{23}$ Lincoln's Inn. (1896-2001) The records of the Honorable Society of Lincoln's Inn: the black books, 1420[-1965]. London, Lincoln's Inn. 6 vols

${ }^{24}$ Inner Temple. (1896-2011) A calendar of Inner Temple records, 1505[-1845]. London, Inner Temple. 9 vols. Only vols 1-5 (1505-1800) and vol. 9 (1836-1845) were issued in published form; vols 6-8 were only prepared in typescript, but all nine vols have been digitised and are available at http://www.innertemple.org.uk/history/caldendars-of-inner-temple-records-1505-1845

${ }^{25}$ Middle Temple. (1905-1970) Minutes of Parliament of the Middle Temple, 1501[-1747]. London, Middle Temple. 5 vols. Only vols.1-4 (1501-1703) were issued in published form; vol. 5 was only prepared in typescript.

${ }^{26}$ Gray’s Inn. (1901-1910) The Pension book of Gray’s Inn: records of the Honourable Society, 1569[-1800]. London, Gray’s Inn. 2 vols

${ }^{27}$ The first was compiled and published by John Browne in 1775 as Browne's General Law List, and was published in various editions until 1801 by which time it had become annual; it was succeeded by 
The New Law List (1798-1802), Clarke's New Law List (1803-1840), and then The Law List (18411976).

${ }^{28}$ Report of the Committee of Privy Councillors appointed to inquire into the interception of communications [Chairman: Sir Norman Birkett]. London, HMSO, 1957. Cmnd. 283 